\title{
EFL Teachers' Teaching Intercultural Communication and Four Skills through "American English Files 2" Textbook and the Reasons for Their Teaching Practices, A Case at an English Center in Can Tho City, Vietnam
}

\author{
TruongThi Kim Khoa ${ }^{1}$ and PhamQuang Huy ${ }^{2}$ \\ ${ }^{1}$ Department of English Teacher Education, \\ School of Foreign Languages, Can ThoUniversity, \\ Can Tho City, Vietnam \\ ${ }^{2}$ Dong Thap Community College, Vietnam
}

\begin{abstract}
The article discussed outstanding issues in how teachers taught Multicultural Communication (ICC) and four English skills through the English textbook "American English Files 2" at a language center in the Mekong Delta, Vietnam. The concepts of culture, multiculturalism, teaching and supporting teaching tools as well as the reasons for choosing those teaching tools were identified respectively. At the same time, multicultural contents were exploited when teachers combined four basic language skills (Listening, Speaking, Reading, and Writing). The relationships and benefits of combining multicultural teaching with skills were also presented. Furthermore, factors such as instruction, curriculum and textbooks that impacted the success and failure of cultural instruction for Englishas Foreign Language (EFL) learners at the center would be described. In addition, many other teaching aids such as Information Technology (IT), supplementary materials, or other ICC teaching and learning techniques would be explored. Data analysis results from tools, namely questionnaires and interviews would be described, analyzed and commented. What's more, the assessment of intercultural awareness and the use of supplementary tools in the lessons would be depicted. Furthermore, the advantages and disadvantages of using complementary tools to teach ICC and the four skills in a language classroom where student willingness was critical were mentioned after data analysis.
\end{abstract}

Finally, some discussions and conclusions were raised.

Keywords:Intercultural communication (ICC), multicultural teaching, teaching Multicultural Communication (ICC) through books, awareness of ICC teaching, supporting tools for teaching ICC, teaching ICC of the teacher

\section{Introduction}

Crystal (1997) asserts English is the world language rather than the property of any particular country. It is still a popular language around the world, is used to communicate among people in different countries so English becomes a compulsory subject at Vietnamese schools. The aim of English language training programs is to educate learners to become global citizen who can deal with linguistic and cultural diversities and participate in multicultural circumstances. Moreover, the teaching of English has been supposed to go beyond the teaching of cultures of the target language, i.e. the teaching of culture should focus on not only its target language cultures but also other cultures around the world where English is commonly used as a communication tool, in order to meet an increasing demand of students' intercultural communication (ICC). However, the integration of intercultural content into English language education is still blurred in the Vietnamese background. Besides, a new trend in integrating intercultural content into English language lessons in order to train English language learners to be competent in both English 
language and IC in order to be able to effectively and appropriately communicate with people from different cultures. Therefore, learning ICC from the contents of textbooks brings EFL learners together, they may have a chance to show their ICC knowledge in multicultural background.

Investigation on ICC in EFL classrooms is very significant to contribute useful instructional material for not only Cross-Cultural Understanding Course but also other related subjects For those reasons, the lecturers will consider reestablish their strategies to fill the intercultural communication in the syllabus to enlarge the students' insight of intercultural communication. Therefore, the students will reinforce and enhance their effective competence of the diversities of culture as the way to gain an effective communication wherever they are. These are the reasons why the researchers conduct the research. Additionally, college students, who want to improve their English skills, take part in the English general course in foreign language centers. Moreover, it is extremely competitive between offline learning market and online one, learning from multiplesources is understandable. Learners can free to choose face-to- face classroom or online learning platforms.

Byram, (1989) emphases foreign language coursebooks has still represented the core of foreign language education, they have a great impact on what is taught and how it is taught in the foreign language classroom. If learners decide to study on or off line, they have to need textbooks. Maintaining that textbooks do not only show the visible center of any English language training program, but also offer benefits for both teachers and students considerably (Sheldon, 1988). Teachers can practice their teaching skills through textbook's contents; they also transfer their knowledge to students by lessons' explanation. However, teaching Intercultural Communication through a textbook has not been studied yet. These are the reasons why the authors do their research about "EFL teacher's teaching intercultural communication and four English skills through American English Files 2 textbook and the reasons for their teaching practices". In order to encourage students feel more motivated in teaching four language skills, teachers integrate to teach ICC and four language skills by supporting tools. The researchers conduct the two research questions in this study which would be formed as follows: (1)To what extent do EFL teachers teach ICC and four language skills through American English Files 2 textbook? and (2) What are the reasons underlined for teachers' teaching practices? With its objectives (1) to study how EFL teachers teach ICC and four language skill through American English Files 2 textbook, and (2) to find out the reasons are underlined for EFL teachers' teaching ICC and four language skills by using supporting tools (ICT tools, extra materials, or other options.

\section{Review of Literature \\ 2.1. What cultureis}

Definitions of culture vary. According to Storti (1999), culture represents the shared beliefs, values, and assumptions of a group of people that in turn influence behaviour. Culture manifests itself in both artifacts and behaviour (Byram, 1997), which can be conceptualized as objective and subjective culture, respectively (Bennett, 1998). Objective culture includes cultural institutions and cultural products such as art, literature, music, food, dress, and festivals-the observable features of a particular culture; subjective culture describes features that are not easily visible, such as values and ways of thinking that inform behaviour. In Bennett's (1998) view, "understanding objective culture may create knowledge, but it doesn't necessarily generate competence" (p. 3) in face-to-face cross-cultural interactions. Traditionally, the focus in education has been on static objective culture; however, an understanding of the dynamic nature and subjective features of culture is essential for enhanced intercultural competence.

\section{2. What Intercultural Communication means}

Effective intercultural communication occurs when meaning is both shared and constructed. Language and culture are deeply connected, in that culture shapes language use and language conveys cultural meanings (Bennett, 1998; Byram, 1997; Jordan, 2002; Kramsch, 1993).Without shared assumptions, values, and beliefs, communication can be difficult or awkward, as interlocutors need to overcome both cognitive and affective barriers (Byram\& Feng, 2004; Tsai \& Houghton, 2010). Stereotyping, ethnocentrism, prejudice, discrimination, and cultural distance are some of the factors that can contribute to intercultural miscommunication (Bennett, 1998; Sharma, Tam, \& Kim, 2009). Durocher (2007) argued that interculturalcommunication comprises skills (e.g., cultural adaptation strategies) that are both distinct from, and complementary to, language proficiency. Without these skills, individuals from different cultures will risk misunderstanding one another, even if they are fluent speakers of the same language. An intercultural approach to language teaching supports learners in acquiring cultural skills as they develop proficiency in the traditional four skills (reading, writing, listening, and speaking) (Corbett, 2003). Consequently, a combination of language skills, knowledge, and intercultural communication strategies are necessary for the 
development of intercultural communicative competence.

Intercultural contact and communication in this globalized era make approaches to understanding and negotiating cultural differences critical for successful interaction. However, the acceptance of, and sensitivity to, cultural differences are neither instinctive nor natural aspects of human behaviour(Bennett, 1998). Rather, cultural differences have the potential to generate conflict, since communicating meaning becomes difficult when there is a lack of a shared language, behavioural patterns, and common values (Bennett, 1993). Therefore, intercultural competence is becoming increasingly relevant across a wide range of disciplines, particularly language education. Byram's (1997) assertion that "teaching for linguistic competence cannot be separated from teaching for intercultural competence"(p.22) reflects the important relationship between language and culture in English language teaching. It is essential for instructors to develop learners' intercultural communicative competence for use both within and beyond the English as a second language (ESL) multicultural classroom. The inclusion of intercultural communicative competence in the Alberta Teachers of English as a Second Language (ATESL)(2011) Adult ESL Curriculum Framework demonstrates the relevance of this issue for curriculum developers and ESL instructors.

Effective intercultural communication occurs when meaning is both shared and constructed. Language and culture are deeply connected, in that culture shapes language use and language conveys cultural meanings (Kramsch, 1993). Without shared assumptions, values, and beliefs, communication can be difficult or awkward, as interlocutors need to overcome both cognitive and affective barriers (Byram\& Feng, 2004 ;). Stereotyping, ethnocentrism, prejudice, discrimination, and cultural distance are some of the factors that can contribute to intercultural miscommunication (Bennett, 1998; Sharma, Tam, \& Kim, 2009). Durocher (2007) argued that intercultural communication comprises skills (e.g., cultural adaptation strategies) that are both distinct from, and complementary to, language proficiency. Without these skills, individuals from different cultures will risk misunderstanding one another, even if they are fluent speakers of the same language. An intercultural approach to language teaching supports learners in acquiring cultural skills as they develop proficiency in the traditional four skills (reading, writing, listening, and speaking) (Corbett, 2003). Consequently, a combination of language skills, knowledge, and intercultural communication strategies are necessary for the development of intercultural communicative competence

2.3. The relationship between culture and International Communicationcomponents in "American English Files 2" textbook

Although four levels of American English Files textbooks showed frequent reference to UK and USA in the reading texts. Within American English Files series, the authors expect to determine the scope of the intercultural aspects consideration only in American English Files 2 textbook. Ziaei (2012) implied the difference among research methodologies such as setting out to analyze photos, dialogues, writing and speaking activities or collecting data leads to the different results of studies. From the early culturally traditional observations, researchers trend to modernize the observation of EFL to intercultural. I totally agree with this point of view.

According to Valiyev A. (2017), the term of "Culture", "Intercultural Communication" are main part of modern developing society. The term "culture" plays a major role when the theories of international relations, which explain and analyze international issues and problems so there is special consideration to the role of culture in international relations, in other words to Intercultural Communication, outstanding aspect of social life has been involved in a systematic study. Culture aspects and Intercultural Communication are put into EFL textbook with the EFL pedagogical purpose at the same time. Research also identified that explanation of culture, the role of culture in communication process, how intercultural communication as a tool among world community. Culture forming as language input and intercultural communication shapes as language outcome.

Besides, Benahnia (2012) claims that beginner EFL learners express their excitement, self-confidence and the ability to communicate to others about their own culture immediately when they have chance. For example, beginners are able to share with their friends or other people about their nationality, hometown, hobbies, etc. Then, learners go into higher level of their language learning process, they get closer to a bigger scope of target culture so the chance to become familiar with a wider range of the cultural elements in target language is given to learners. These knowledge of cultural elements are contained in the intentionally chosen EFL textbook. They voluntarily take a general English course in foreign language center so as to improve their English ability. As Kramsch (1993) stated that intercultural competence mentions EFL learners' idea must be enjoy the ability of understanding both home culture and foreign/target culture. Similarly, Bryam (2002) defined Intercultural Communicative 
Competence means "ability to ensure a shared understanding by people of different social identities, and [the] ability to interact with people as complex human beings with multiple identities and their own individuality".

Therefore, EFL teachers' decision in selecting American English Files 2 (American EF2) for their teaching throughout a general English course in the language center that satisfies both students' need and center's teaching orientation as well as teaching professional development of EFL teachers.

\subsubsection{Intercultural attitudes}

Bryam, Nichols and Stevens (2001) defined intercultural attitude refers to "curiosity and openness, readiness to suspend disbelief about other cultures and belief about one's own". It promotes readiness to communicate with others.

An example of discussing the different things that you see in the photos of unit 3D (p.34), a patient told about his dreaming and then students try to encode the meaning of dreams by their own experience instead of listening psychoanalysts' analyzing. In doing so, the photo will help students develop curiosity for newness and build the open-minded point of view in personality. Some people believe their dreams related to supernatural or superstitions but others believe that their physical and mental are suffering pressure or stressful. Different students think about the photo of textbook in different ways so that they have chance to brainstorm and feel get involved.

"American English Files 2" textbook tries to build a positive international attitude. In the connection, a female Brazilian and American interviewer talk about looking for a job in New York City (Unit 3A, p.28). Here, listeners can hear information infers that it is easy to find a job in one of the biggest and busiest cities of the world and speaking English is not a big trouble because Brazilian lady is able to learn from American TV channel every day and working environment. Going to English class will be an option not the first priority.

Cortazzi and Jin (1999) realize that developing personal identity is one of the important targets of intercultural attitude. It draws learners' ability to understand one or more cultures and the social identities of whom they are interacting with (Byram\& Fleming, 1998). In Lesson 1 "Not next to me, please!" (Unit 1, p.15) students are asked to identify and match the headings with paragraphs, they perceive and react politely while using international transport or public service as well as respect individual in public places. Another example, three customers are interviewed for fashion products which are named a well-known trademark of the world, Zara (Unit 4A, p. 40)They show their feeling about Zara product whether their comment are positive, neutral or negative, interviewer does not criticize his customers' opinions. Similarity, speaking pair-work activity on page 31 guides students how to give compliment, positive reaction to their partners by the positive phrases. These lessons encourage EFL students' suitable reaction of intercultural attitude lead them into a better understanding and respect for people who comes from different situations/background. Therefore, these textbook activities aim to expand learners' awareness of the differences even within a culture.

\subsubsection{Intercultural knowledge}

Byram et al. (2001, p.6) claim that intercultural knowledge connects the "knowledge of social processes, and knowledge of illustrations of those processes". This theory require both teachers and students have the knowledge of social groups, the knowledge about other people, country, culture, cultural practice, social manners, behavior, lifestyle. Therefore, teaching Intercultural contents is not easy for EFL teachers. He/she continuously upgrades their knowledge in this field to adapt real situations and textbook's contents. An example of knowledge of new places and new social practices are found in textbook. Lesson "The place where I live" (unit 4, p.49) introduce students to know more about the second biggest city of Mexico is Guadalajara, which is located in the state of Jalisco, owns not only full of monuments, fabulous colonial architecture but also mariachi bands and mariachi festival annually. During providing some information about this city, teacher can guide students compare the Guadalajara with students' hometown or other cities of the world. After that, students will descript the places they live, they may use comparative structures or superlative structures, or find out the similarity and differences from Guadalajara's lifestyles, market, weather, population, history events.

\subsubsection{Intercultural Communication}

Byram's (1997) point of view clarifies intercultural communication means an interaction between people of different languages and countries where one is a native speaker of the language used; and between people of different languages and countries where the language used is a lingua france.

In Lesson 3A, Airport Stories (p28) of textbook a couple comes from Nagasaki, Japanese have a conversation with an interviewer. While being interview, they are asked "Where are you staying in New York?", "What are you planning to do?", "When are you leaving?".

Thorough conversation, Maki and Koji are planning to see a Broadway show which is one of the most popular shows in New York City. Also, Yankee 
stadium that is a baseball park located in Concourse, Bronx, New York City. As readers can see, Japanese couple adores and have basic knowledge about New York tourist sites that help readers have more knowledge about NYC. In this case, the interviewer plays as a native speaker get information from Japanese couple. Another example, Journalist Tim Moore went to three cities Rome, Paris and New York. The situations show Tim can talk to many inhabitants during carrying out the photo test, the shopping test, the accident test, he give opinions and evaluate which city is the friendliest one. Besides, traveling to countries with confidence, enjoyment and interest make his stories more colorful and wonderful. (Lesson 4D, The world's friendliest city, p. 46). Later, the activities here lead students to a simulated situation. Specifically, they are asked to their tour with the following cues "the coldest place you've ever been to" "the most beautiful building of the world you know", "Where are you going on vacation?", and "What are you planning to do there?" (pp.110-116).

\subsection{Teaching intercultural communication in American English Files 2 textbook}

Nelson (1994) declared that recognition and reflection of learner' source culture in language teaching is essential because it is hard to get students' involvement and participate in teaching-learning process without their original culture, and their identities. Similarly, Byram and Morgan (1994) indicated that EFL students cannot deny and negate their own culture and go into another as their culture is a part of themselves and created them as social beings.

Belief and religions of Vietnamese has being influenced mostly by Buddhism, Taoism and Confucianism which are known as the triple religion in Vietnamese culture. Besides, Vietnamese religion are built from Christian, Buddhism, Hinduism, etc. Ancestor worship, which is also the beauty in Vietnamese culture value, has existed in Vietnam for a long time. Up to now, Vietnamese people have preserved the worship to show respect to the deceased. Additionally, Vietnamese culture presents in the way of local greeting, social distance between elders and their children, social face, the polite behaviors, traditional customs, traditional festivals. In comparison with the target and international target cultures, it is noticed that the students' source culture was given an imbalanced consideration. The finding of Ehya, A., Reza, K. and Mehroosh, D. (2014) mentioned this side in their research about exploring culture content of American English Files 2 textbook. Consequently, the importance of EFL teaching process means to resemble teacher's own cultural experience to other prominent cultures in American
English Files 2 textbook. The conclusion of combination provides not only students feel familiar with, but also a means to develop their multi-cultural consciousness. Students are supposed to match up their culture to the intercultural target.

\subsubsection{The four criteria for evaluating English textbooks}

Cunningsworth (1995) proposes four criteria for evaluating textbooks, particularly course books as the following reasons:

Firstly, they should meet learners' needs. They should match the aims and objectives of the language-learning program. That is the reason why the foreign language center of this study use American English Files 2 textbook (Block units 1 to $5)$. The book is used for EFL students (level A2-B1). EFL teachers have to train both senior students and junior one more and more confidently in speaking English. Also, one of the most benefits after finishing the General English courses (periods 1 and 2) of students is challenges their English learning ability through the final examination to get certificates.

The second criteria are textbooks should be chosen that will help equip students to use language effectively for their own purposes. Students need to improve their English skills to pass the job interview after graduating. They may speak or write English for their customers oversea or read the English documents in some cases. Almost EFL learners in the foreign language center come from different majors such as: Financial Banking, Hotel Management, Law, Vietnamese, Information Technology, etc. During joining in the general English course, they share the same platform that equip themselves English proficiency ability in make a conversation in any suddenly situations.

The third criteria for evaluate a good English language book that "textbooks should take account of students needs as learners and should facilitate their learning processes, without dogmatically imposing a rigid method". American English Files 2 textbook series can be satisfied students' need which always remains diversities by a lot of different topics (e.g dating, reservation, super-stars singer lifestory, dreams, immigrants, vacations, etc). Hence, students can practice English in every single hypothesis situation or real life one. American English Files 2 textbook in the series is designed and produced by colorful and high quality papers which many descriptive images. The contents forms are arranged creatively and flexibly from lesson to lesson to encourage students' curiousness in learning English language as foreign one. Vocabulary bank is drawn by fun photos and easy to guess the meaning from contexts. 
The final criteria are textbooks should have a clear role as a support for learning. If teachers play roles as operators, leaders or managers, they mediate between the target language and the learner. Book is a mean transfer English knowledge and skills' lessons to EFL students.

\subsection{EFL teachers' perception in teaching Intercultural Communication}

Teaching Intercultural Communication primarily focuses on helping students to make them understood. They can express their ideas by words, sentences and they need to worry much about cultural issues. In addition to, teachers need to make students aware of cultural aspects or contents, and this cultural awareness can help them to build good first impressions and communicate better.

The findings of Kasma and Kanchana (2017) in a research are that ICC as something involving communication between people from different cultures. Four key elements of ICC are perceived by teacher participants. The first element was cultural differences between communicators. EFL teachers of course can speak and teach by English languages but all of them come from different background (e.g. ages, hometowns, hobbies, social activities, eating habit, life point of view, etc) so their thought and behaviors are different. For instance, if someone says hello as a way of greeting, the other decides to nod their head. Another, if somebody wants to eat breakfast with noodle soup, other starts their day meal with "bánhmi”"(Vietnamese) or "sticky rice". Closely linked with the first element, the second element was an awareness or understanding of such cultural differences. The next element was that Intercultural Communication content occurred in communication that was made through a lingua franca. Finally, Intercultural Communication involved a use of body or nonverbal language.

\subsection{Techniques in four skills of an English textbook}

According to Prabhu (1987), there are seven types of Task-based learning task. They can be small scale (e.g. a listing task) and take just 5-10 minutes of a lesson, or they can be large scale (e.g. a project) and take one or several lessons to complete. Teacher, who wants to design lessons, having a sequence of different types of tasks, generates free language uses and produces an outcome that can be shared with others.

Listing activity: brainstorming and/or fact finding

This could be about things, places, people, things to do, the reasons for things, the qualities and features of different things and places.

Ordering and sorting activity: sequencing, classifying, ranking
Sequencing words or pictures into the correct order for a particular process or historical event, classifying things according to their properties, ranking things in term of their importance.

Matching activity:

Matching words with pictures, matching definitions with words, listening and identifying objects and features, listing and doing (e.g. Total physical response (TPR) and following instructions)

Comparing activity: finding similarities and differences

Comparing and contrasting different things, properties, substances, objects, procedures, times, places, "Spot the difference".

Problem-solving activity: logical problems, real-life problems, incomplete processes, incomplete texts

Predicting the outcome of an experiment or event, solving a mathematical problem, proposing a solution for a particular problem, presenting a solution to the problem

Project and creative tasks

A poster presentation (on paper or an online version) on a topic area, making a video of an experiment or about a particular topic

Sharing personal experiences: opinions, reactions, experiences

Personal opinions, views and experiences related to a particular topic.

Task-based Intercultural Language Teaching is an experience-orientated approach that concentrates on the process of interaction and exploration rather than assimilation and passive intake. Language users enable to use the language for the purpose of communication in various social contexts. According to Liddicoat, et al. (2000) put it, "language cannot be considered just as a set of purely linguistic skills. And the language learner needs to move beyond what she/he functions within cultural borders. This is the core of the process of the process of moving towards a bilingual norm". Moreover, using a taskbased approach brings learners use language productively; they have the freedom to express what they want to say, they also questions about content and language to complete the task. A task-based learning activity can be tasks on a small or large scale. It is suitable for mixed ability classes as learners work at their own level. The focus on the product encourages both content and language acquisition.

Role Play: A practical way to teach Intercultural Communication

Role-play approach combined intercultural dimension is an effective approach to language learning in CLIL teaching. An opportunity to learn and develop student's language skills is a creative condition. Students play a main role in makingdecision and innovation, teachers now as moderators/ facilitator. Therefore, breaking the traditionally 
educational environment down, providing students with a motivating and interesting forum which mixes communication, culture, content and cognition to receives professional and practical learning outcomes. Role play activity is both a useful way to teach intercultural communication and a very pragmatic means of encouraging them in the development of their meta-cognitive skills. Consequence, role play is the best choice for oral activity and its effectiveness spread to spiritual learning of students namely: having effective in group work, more advantages than working alone, learning form teammates, training the ability of well-preparation, a usefulness of peer review.

\section{Using jigsaw model to improve reading comprehension}

In this way, a model of teaching reading in class has been creating which called the Jigsaw model of cooperative learning strategies by educators. Slavin (1995) addressed Jigsaw approach focus on a way to build a community of learners own their value. Group working is the first priority condition of Jigsaw model. Each group member has his own responsibilities with the others teammates (Stone, 1990). He has a brainstorm, collect, analyze the data of pre-reading, while-reading text and then discuss, share his decisions to the others. After analyzing data through skimming and scanning pieces of informative paragraphs of text, he will be able to jump into answering reading questions. Otherwise, others team members should debate or show their agreement or disagreement. All of team members' contribution will consolidate the team spirit and team's solve-problem skills and team maintenance. There are some common reading question types which are presented in American English Files 2 textbook namely: matching headings questions, true false not given/yes no not given questions, matching paragraph information questions, matching headings and paragraphs,, ordering the sequences events questions, multiple choice questions, locating information questions, etc.

\section{Crosspuzzle}

According to Wahyuningsih (2009) defines a Crossword Puzzle, is a game in which words, guessed from their definitions, are fitted into a diagram of white and black squares. The crossword has words written horizontally and words written vertically. The pattern of black squares usually serves to separate each word from adjacent words. In crossword puzzles, the blank squares are ordered with number assigned to some of square. Students have to exactly fill in all the blank squares with Alphabet letters those form words. The clues are provided to students so as to encode the words in puzzle, which can be complete sentences such as definition, concepts, idioms, phrases or words. It is one kind of game so this is an educationally enjoyable activity instead of multiple choice question tests only.

One of an example for using puzzle in teaching speaking part of lesson A devil dictionary of American EF2 textbook, teacher asks EFL students work in pair. During students A and B give clues, they have a chance to practice speaking and listening their partners. After that, they enable to guess the meaning of words and fill words in the puzzle. Therefore, Moore \& Dettlaff (2005) say students have to spell words correctly to complete the puzzle so that they gain greater recalling information and memorization of vocabulary.

\subsubsection{Techniques in tasks of speaking skill}

Gibbons (2006) proposes that the scaffolding of learning and teaching activities and the association of oral or written tasks in the Content and Language Integrated Learning (CLIL) classroom. Mortimer and Philip (2003) give evidence that to enhance the effectiveness of students learning teachers should use role-play activity in classroom. The combination of two approaches established the stages namely review and orientation, arranging the new task, brainstorming the task, and reflection on task. Then, some next steps coming likely role-play practice, performing the role-play task, feedback and peer review, and evaluation and assessment.

Additionally, role-play offers multiple opportunities to practice a foreign language than any other teaching activity. (Lee and Smagorinsky, 2000). It also strengthens students' confidence to use English as a Foreign Language in contextualized environments (Zhang, 2010). Learners have chance to put themselves in the available conversation so they enable to practice pronunciation, communication skills, the organization of ideas, group understanding, interpretation and inferring. Therefore, using this technique EFL teacher will motivate and encourage not only students' communication skills improve but also students' "quality of thought, argumentation, analysis, synthesis, explanation, evaluation on the usage of the foreign language" (Marin and De La Pava, 2017, p. 86).

Besides, role-playing activity gets students more involvement and creates a fun and exciting environment. Meanwhile, teaching and learning plans should be included Role-play to build an opening atmosphere for learning a foreign language, help students to achieve English language in a more realistic way.

\subsubsection{Techniques in tasks of listening skill}

Listening is a process of understanding the sounds that is being heard. The listeners do not only need to understand it, but then process the information that is 
spoken by the speaker. Similarly, listening as the active, purposeful process in making sense of what we hear. Nunan also mentioned that as people who listen, they process not only what they hear, but also connect it to other information they already know. As they find any connection between what they are listening and what they are known before, the listeners will understand about what they had listened. Listening is one of skills in language and it is the key to all effective communication.

\subsubsection{Techniques in tasks of reading skill}

In this way, a model of teaching reading in class has been creating which called the Jigsaw model of cooperative learning strategies by educators. Slavin (1995) addressed Jigsaw approach focus on a way to build a community of learners own their value. Group working is the first priority condition of Jigsaw model. Each group member has his own responsibilities with the others teammates (Stone, 1990). He has a brainstorm, collect, analyze the data of pre-reading, while-reading text and then discuss, share his decisions to the others. After analyzing data through skimming and scanning pieces of informative paragraphs of text, he will be able to jump into answering reading questions. Otherwise, others team members should debate or show their agreement or disagreement. All of team members' contribution will consolidate the team spirit and team's solve-problem skills and team maintenance. There are some common reading question types which are presented in American English Files 2 textbook namely: matching headings questions, true false not given/yes no not given questions, matching paragraph information questions, matching headings and paragraphs,, ordering the sequences events questions, multiple choice questions, locating information questions, etc.

\subsubsection{Techniques in tasks of writing skills}

In term of using approaches to the teaching of writing skills, Walsh (2010) points out writing is the important skill because of without writing students do not know how to express themselves through penand-paper, they won't be able to communicate well with professors, employers, peers, or just about anyone else. Most of professional communication is done in writing: emails, applications, reports, or daily life story, individual thought. Hence, two most common approaches are applied in teaching writing skills. The product approach to writing usually involves the presentation of a model text, which is discussed and analyzed. According to this model text learners construct a similar or a parallel text. This might seem a mechanical task; however, learners can discover the structure of the given discourse, its linguistic features and how its ideas are organized. The process approach to writing in contrast focuses on the development of languageuse: brainstorming, group discussion, re-writing. Steele (2004) developed a comparison between the process approach and the product is given below:

\section{Process approach}

- Text as a resource for comparison;

- Ideas as starting point, necessitating more than one draft;

- $\quad$ Focus on purpose, theme, text type ...;

- The reader (audience) is emphasized;

- Collaborative with other peers;

- Emphasis on creativity.

Product approach

- Imitate a model text;

- Organization of ideas more important than ideas themselves;

- One draft;

- Features highlighted including controlled practice of those features;

- Individual;

- Emphasis on end product.

Using Pictures in teaching writing is one ofthebenefits of using pictures in EFL classroom. According to Aschawir, A. (2014), there are many benefits of using pictures during teaching process such as making the input more practical and significant, helping students to swell more on textbook's task or assignments, and making EFL classroom more exciting by building connections between textbook's tasks and real world.

Visual images can enhance teaching and learning process in EFL classroom. It is good as pedagogical representation of visual images in textbook (multimodal perspectives). Similarly, Sadiyah's research indicates that teaching writing enables to promote students' competencies for writing descriptive texts thanks to using the integration of visual cues. Also, this tool will improve students' involvement and attitude towards the learning process, rising students' enthusiasm to join in the class activities, increasing interaction among classmates, and help teacher-students interaction in classroom. Classmates can share the same visual cues of textbook and discuss together about the way to design the frame or scaffolding of writing tasks.

Otherwise, the previous studies indicate that it is difficult for students to learn writing skill. This difficulty comes from a large number of external and internal factors affecting EFL writing. Students are scared of making mistake while writing grammatical sentences such as: errors tenses, possessive adjective, punctuation, spelling, etc. A few students cannot express their ideas thorough writing tasks about personal information, and unable to describe the events or situations, even make questions for simple requirements without English language online software or smart phone. It is believed that 
successful writing requires not only foreign language proficiency, but also cross-cultural and discourse knowledge (Xing, Wang \& Spencer, 2008).

\section{Materials and Methods \\ 3.1. Materials}

\section{American English Files 2 textbook}

Jack C. Richards is an Adjunct Professor at SeameoRelc. His most recent book is Curriculum Development in Language Teaching. Jack C. Richards (2001), textbooks are often gone along with workbooks, CDs, and cassettes, video, CD, ROMs and comprehensive teaching guides, providing a rich a varied resource for teachers and learners. The above reasons lead to the integration of potential extra resources beyond the textbook fit for purpose of curriculum program as well as both teaching and learning processes.The group of author namely Christina Latham-Koenig, Clive Oxenden, Paul Seligson, Mike Boyle designed American English File to get students talking thanks to its unique and proven formula combining confidence-building, opportunity, and motivation. High-interest content is organized in lively, achievable lessons, using humor and imagination to encourage students to communicate and enjoy learning English. Solid grammar, vocabulary, and pronunciation foundation carefully supports the work with the four skills and gradually builds students' confidence and performance in English. With a wide range of exciting new digital material, including all new documentaries, this new edition of American English File is still the number one course to get your students talking.

\subsection{Methods}

\subsubsection{Research design}

Using mixed-method is the priority choice for this paper' data solving because they own a lot of positive features for this research as below:

- The researcher's aim place a theoretical and practical study of teaching ICC through American English Files 2 textbook (four basic skills: Speaking, Listening, Writing, Reading)

- It is the most appropriate approach to satisfy my research questions and standard evaluations called how EFL teacher's teaching Intercultural Communication and the reasons which are underlined for their decisions. According to Johnson et al (2007, p. 123) defined Mixed methods research is the type of research in which a researcher combines elements of qualitative and quantitative research approaches (e.g.,
ISSN 2455-6378

use of qualitative and quantitative viewpoints (interviewees' opinions, measuring instruments, data collection, analysis, inference techniques) for the broad purposes of breadth and depth of understanding and corroboration. A mixed methods research study means components of a research design are types of scientific research.

\subsubsection{Participants}

There were six lecturers who have got Master degrees reached 60 percent. The numbers of participants who are in process of taking Master degrees (Bachelor degrees) have 40 percent. Three junior teachers have 1 to 5 years of teaching English textbooks experiences (30\%). Four senior lecturers alternately have 5 to 10 years $(20 \%)$ and 10 to 20 years $(20 \%)$ of teaching English textbooks experiences. The percentage of the three lecturers who were the most experienced in teaching English textbooks showed $30 \%$. Additionally, one lecturer has 1 to 2 years of teaching AEF 2 textbook reach only $10 \%$. Of the total number of rich experienced lecturers in teaching AEF2 textbook, six respondents who have experiences from 3 to 5 years $(60 \%)$ and three of them have experiences from 6 to 10 years (3\%).

There were 30 EFL junior and senior students took part in answering the study's questionnaire that accounted for $43,3 \%$ of male and $56,7 \%$ of female. The participants' ages are from 18 to 23 years old and they spent at least 3 months joining in the General English class at foreign language center. The percentage of students came from business major is $20 \%$, some of students learnt other majors namely: Tourist Administration, Vietnamese Language, Information Technology, Building Construction that make up $80 \%$.

\subsubsection{Research instruments}

Instruments are questionnaire designed as semistructured questions which follow the literature review.

\section{Results and Discussions}

The data collected from the questionnaire were inputted into the SPSS data 20.0 version. The researcher ran the scale test to test the reliability of the questionnaire. Table 4.1 presented the reliability coefficient of the questionnaire accorded to the statistical reliability $(\alpha=0.689)$. Consequently, the questionnaire is reliable for data collection.

4.1.EFL teacher's teaching ICC and four language skills through American English Files 2 textbook (Units 1 to 5): 
-Frequency of EFL teacher's teaching ICC and Listening skill of AEF2 textbook by supporting tools

The Descriptive Statistic Test was dominated to examine the means scores of EFL lecturer's teaching ICC and Listening skill of American English Files 2 textbook (Units 1 to 5) regarding how regularly they integrated to teach ICC and Listening skill of the textbook by supporting tools. The result is presented in table 4.1 below

\begin{tabular}{|c|c|c|c|c|c|}
\hline & $\mathbf{N}$ & Min & Max & $\mathbf{M}$ & SD \\
\hline $\begin{array}{l}\text { The } \\
\text { frequency } \\
\text { of EFL } \\
\text { teacher's } \\
\text { teaching } \\
\text { ICC and } \\
\text { Listening } \\
\text { language } \\
\text { skill of } \\
\text { AEF2 } \\
\text { textbook } \\
\text { by } \\
\text { supporting } \\
\text { tools }\end{array}$ & 10 & 3.04 & 4.50 & 3.60 & 0.39 \\
\hline $\begin{array}{l}\text { Valid } \mathrm{N} \\
\text { (listwise }\end{array}$ & 10 & & & & \\
\hline
\end{tabular}

Table 4.1 showed that the total mean scores of the cluster on the frequency of EFL teachers' teaching ICC and four language skills through AEF 2 textbook by supporting tools $(\mathrm{M}=3.6)$ were high in the five-degree scale.A One-Sample T-Test was run on the total mean scores of the frequency of EFL teachers' teaching ICC and Listening skill through AEF 2 textbook by supporting tools and the test value 3.5 .

-Frequency of EFL teacher's teaching ICC and Reading skill of AEF2 textbook by supporting tools

\begin{tabular}{|l|l|l|l|l|l|}
\hline & N & Min & Max & M & SD \\
\hline $\begin{array}{l}\text { The } \\
\text { frequency } \\
\text { of EFL } \\
\text { teacher's } \\
\text { teaching }\end{array}$ & & & & & \\
$\begin{array}{l}\text { ICC and } \\
\text { Reading } \\
\text { skill of } \\
\text { AEF2 }\end{array}$ & 10 & 3.29 & 3.96 & 3.55 & 0.22 \\
$\begin{array}{l}\text { textbook } \\
\text { by } \\
\text { supporting } \\
\text { tools }\end{array}$ & & & & & \\
\hline $\begin{array}{l}\text { Valid N } \\
\text { (listwise }\end{array}$ & 10 & & & & \\
\hline
\end{tabular}

Table 4.2 showed that the frequencies of EFL teachers' teaching ICC and Reading skill through
AEF 2 textbook by supporting tools was $\mathrm{M}=3.55$ as high level ( $\mathrm{SD}=0.22$ ). This indicates revealed that teachers usually integrate to teach ICC and Reading skill through supporting tools

-Frequency of EFL teacher's teaching ICC and Writing skill of AEF2 textbook by supporting tools

\begin{tabular}{|l|l|l|l|l|l|}
\hline & N & Min & Max & Mea & SD \\
\hline $\begin{array}{l}\text { The } \\
\text { frequency } \\
\text { of EFL } \\
\text { teacher's } \\
\text { teaching }\end{array}$ & & & & & \\
$\begin{array}{l}\text { ICC and } \\
\text { Writing } \\
\text { skill of }\end{array}$ & 10 & 3.19 & 3.81 & 3.50 & 0.21 \\
$\begin{array}{l}\text { AEF2 } \\
\text { textbook } \\
\text { by } \\
\text { supportin } \\
\text { g tools }\end{array}$ & & & & & \\
\hline $\begin{array}{l}\text { Valid N } \\
\text { (listwise }\end{array}$ & 10 & & & & \\
\hline
\end{tabular}

Table 4.3. displayed that the frequencies of EFL teachers' teaching ICC and Writingskill through AEF 2 textbook by supporting tools was $\mathrm{M}=3.50$ as medium level ( $\mathrm{SD}=0.21$ ).

-Frequency of EFL teacher's teaching ICC and Speaking skill of AEF2 textbook by supporting tools

\begin{tabular}{|l|l|l|l|l|l|}
\hline & N & Min & Max & M & SD \\
\hline $\begin{array}{l}\text { The } \\
\text { frequency } \\
\text { of EFL } \\
\text { teacher's } \\
\text { teaching }\end{array}$ & & & & & \\
$\begin{array}{l}\text { ICC and } \\
\text { Speaking } \\
\text { skill of }\end{array}$ & 10 & 3.13 & 3.93 & 7.6 & 0.25 \\
$\begin{array}{l}\text { AEF2 } \\
\text { textbook } \\
\text { by } \\
\text { supportin } \\
\text { g tools }\end{array}$ & & & & & \\
\hline $\begin{array}{l}\text { Valid N } \\
\text { (listwise }\end{array}$ & 10 & & & & \\
\hline
\end{tabular}

Table 4.4 showed that the frequencies of EFL teachers' teaching ICC and Speaking skill through AEF 2 textbook by supporting tools was $\mathrm{M}=3.67$ as a high level ( $\mathrm{SD}=0.25$ ). This indicates revealed that the frequency of teachers teach ICC and speaking skill of AEF 2 textbook by supporting tools was high. 
4.2 EFL teachers' perceptions of teaching ICC and four language skills through AEF2 textbook

\subsubsection{Quantitative data}

The results showed that teachers had high perception of teaching ICC and four language skills through AEF2 textbook by supporting tools. Furthermore, the questionnaire was designed to follow the integration of teaching ICC with four language skills. The aspects of ICC teachers would insert into teaching four language skills. They show their opinion by tick in the boxes of online questionnaire. These steps reform reliability and validity in questions and teachers' feedback.

The findings also indicated most of EFL teacher agreed $(60 \%)$ to share with their students about stereotypes regarding, also asked their students to participate in role play situations in which people from different culture meet and strongly agreed (80\%) about giving students the reasons why teachers find something fascinating or strange about the foreign culture or cultures. Moreover, the huge number of teachers absolutely agreed to ask their students to compare an aspect of their own culture with that aspect in the foreign culture in Reading activities. However, few teachers had no ideas in encourage students to compare between Vietnamese cultures and foreign cultures because of students' limitation in presentation as well as their weaknesses of listening comprehension activities. On the other hand, one teacher found that it was difficult to present the differences between Asian meal manners and American one for students under compulsory schedule. Few teachers said that they strongly agreed with the samples or examples, but they proposed others samples similarly.

With the role of society and culture assuming greater importance in recent years, intercultural communication have become progressively outstanding in the field of foreign language teaching as a natural consequence of globalization (Hismanoglu, 2011). Education is interwoven with culture and this fact is even more evident in second language culture, where acquaintance with the target language culture is merely viable through the medium of language. Totally, all of EFL teachers preferred teaching ICC and four language skills together, they aimed to combine these contents in order to draw students' attention and motivation in learning L2.

In addition, the findings indicated most of EFL teacher agreed $(60 \%)$ to share with their students about stereotypes regarding, also asked their students to participate in role play situations in which people from different culture meet and strongly agreed $(80 \%)$ about giving students the reasons why teachers find something fascinating or strange about the foreign culture or cultures. Moreover, the huge number of teachers absolutely agreed to ask their students to compare an aspect of their own culture with those aspects in the foreign culture in Reading activities. However, few teachers had no ideas in encourage students to compare between Vietnamese cultures and foreign cultures because of students' limitation in presentation as well as their weaknesses of listening comprehension activities. On the other hand, one teacher found that it was difficult to present the differences between Asian meal manners and American one for students under compulsory schedule. Few teachers said that they strongly agreed with the samples or examples, but they proposed others samples similarly.

With the role of society and culture assuming greater importance in recent years, intercultural communication have become progressively outstanding in the field of foreign language teaching as a natural consequence of globalization (Hismanoglu, 2011). Education is interwoven with culture and this fact is even more evident in second language culture, where acquaintance with the target language culture is merely viable through the medium of language. Totally, all of EFL teachers preferred teaching ICC and four language skills together; they aimed to combine these contents in order to draw students' attention and motivation in learning L2.

4.2.2 The reasons for teaching ICC and four language skills through AEF2 textbook by ICT application

From the responses of EFL teachers interviewed, here are some comments collected. These cases below show EFL teachers prefer using ICT application in teaching ICC and four language skills:

“[...] create students' motivation and curiousness in learning that topic. Students cannot be embarrassed, confused, and unfamiliar during facing a real situation. Thanking to supporting of ICT, teacher also learn from his/her students."

(Teacher 1)

"“[...]from the students' need, I design the suitable lesson plan to create students' motivation in learning."

(Teacher 2)

"[...] Besides, I sometimes use Power Point, video clips, movies, songs, drama. The potential video clips related to cultural regions, national languages and culture what students were going to study."

(Teacher 3)

“[...] Yes, I do. Supporting tools or extra tasks make the related theories clearer; I also design these extra 
documents. I think Information Technology will be suitable for Introduction part."

(Teacher 5)

At the same token, ICT applications like Powerpoints (PPTs) for teaching L2, teachers wanted to eliminate students' negative feelings such as embarrassed, nervous, shy situations while they were learning. Comparing among ICT applications and others options, teachers chose PPTs, video most frequently in order to introduce foreign contents from textbook to students.

4.2.3. The reasons for teaching ICC and four language skills through AEF2 textbook by extra materials

These cases below showed EFL teachers preferred choosing extra materials in teaching ICC and four language skills through AEF2 textbook as these below reasons:

"[...] accordingly, it is easy for students to apply the sample tasks."

(Teacher 1)

"[...] sometimes, after reading parts of Tomato festivals, then I require students use the contents of Reading for next Speaking parts. Students would know how to make conversation of a festival."

(Teacher 2)

"[...] In my English classes, I usually prefer teaching ICC by Student Book, Work Book, Teacher's Book, handout, black board and chalk."

(Teacher 3)

"[...] I usually use extra materials when teaching practical grammar, or speaking skills. Speaking contents of AEF 2 textbook usually show cultures of target language so most of students find not exciting enough."

(Teacher 5)

Extra materials played useful and important role in teaching L2 as well as ICC in terms of adapting AEF2 textbook. A teacher shared that some types of extra assignments such as work book, portfolios, and assignment sheets would be suitable for students' reflection. Besides, some teachers thought paper assignments eliminated students' demotivated or neglect while approaching new theories and building multiple views for them as well as being active in applying theories into real tasks. The variety of tasks made teachers easy to link ICC contents to 4 skills.

4.2.4. The reasons for teaching ICC and four language skills through AEF2 textbook by other options (Units 1 to 5)

Although teachers preferred using ICT application and extra materials in teaching, other options sometimes work effectively in some cases as teachers' sharing below:
"[...] I divided the class into small groups, each students of groups prepare the lesson contents base on a specific topic. Many students in a group can contribute good ideas make the lessons more meaningful and better."

“ [...] I think I should choose suitable types of games with appropriate cultural contents.

(Teacher 1)

"[...] To be honestly, I seldom organize English games, I have to follow the syllabus of center very strictly”.

(Teacher 2)

"[...] redesign the questions in order to appropriate to students' level."

(Teacher 3)

"[...] I tell stories of national cultures which interrelated to textbook lesson' contents which part I am teaching for students' listening practices. I usually redesign lesson plan to suit with students' level, competence as well as ICC contents of AEF 2 textbook."

(Teacher 4)

"[...] Sometimes, I organize games for students joining in. Students in class have chance to talk together. I think working in group will concentrate on lessons more."

(Teacher 5)

Teachers sometimes applied traditional methods namely black board and chalk, games, techniques of classrooms managements for instance group works, pair works, role-play, instead of using ICT application or extra materials in teaching practices only.

4.2.5. The reasons for teaching $\mathrm{ICC}$ and four language skills through AEF2 textbook contents only. (Unit 1 to 5)

These cases below expressed that EFL teachers preferred teaching ICC and four language skills through AEF 2 textbook only

"[...] students find the answer from the mentioned outline and then link to local festival which students prefer, they can practice Speaking with their partners from their outline contents. Some lessons donot involve ICC contents at all."

(Teacher 2)

"[...]The integration of 4 skills (Listening, Reading, Speaking and Writing) goes through "taking photographs", "shopping accidents", "falling down on the street"."

(Teacher 3)

"[...] To students who are the first time study American English Files 2 textbook series."

(Teacher 5)

According to Byram et al (2002) qualified teachers are not native educators only. English teachers are not certain native speakers of the UK, US, Australia, 
who only must have a lot of experience living and working abroad. Experienced teachers of teaching staff are people who know how to exploit lessons under a deeper cultural perspective, design flexible activities with the goal of teachers are able to design series of learning activities that engage learners into discussing and analyzing from facts they read in accordance with well-established cultural communication aims. The classrooms with internet and e-learning system will help teachers and students to conduct foreign language teaching and learning activities more vividly.

\subsection{Suggestions for challenges of integration teaching and learning ICC and four language skills through AEF2 textbook (Units 1 to 5)}

The data from the questions of the interviews were employed to find the suggestions for challenges of integrating teaching ICC and four language skills through AEF 2 textbook by supporting tools. When being asked about suggestions, participants showed many ideas about the suggestions from the challenges of teaching ICC and four language skills, but they have similar opinions, so here are some specific ideas of each participant in the interview process.

" [...] Some latest years, teachers usually prefer using ICT such as video clips, cassette players, students cannot be embarrassed, confused, and unfamiliar during facing a real situation."

(Teacher 1)

"[...] Depending on each situation, I set up lessons" performance connect to ICT tool to avoid students' demotivation through video (before and after watching video)."

(Teacher 2) "[...] To WB, I have to choose the suitable assignments, updating with lesson contents.

"[...]Secondly, students will know how to write and describe where they live through lesson "Describing yourself" in Writing section. They are able to compare between Vietnam weather and others."

(Teacher 3)

"[...] I tell stories of national cultures which interrelated to textbook lesson' contents which part I am teaching for students' listening practices. Students feel more comprehensive and acquire new intercultural knowledge. It is meaningful and useful for students to use hypothetical situation into real life."

(Teacher 4)

“[...] (Speaking) I train for students' making decisions and protect their ideas. I always integrate to teach with supporting tools."
"[...] I limit supporting tools, redesign valuable contents of the textbook, I want to save time for searching extra materials, also explore $100 \%$ percent the effectiveness of AEF2 textbook."

(Teacher 5)

As educators, all teachers of foreign language center non-stop to keep up with students' demand and school target syllabus in order to create productive output learning. These above suggestions explained how teachers effort to shape students' positive behaviors in learning. For examples, a teacher said that she always calmed down and consistence under some trouble maker in her class. Almost teachers set up the good habits for students in learning L2 such as watching English sub video, songs, or encouraged talk to their partners by English instead of Vietnamese in classroom, or avoiding using translate App while reading time. Besides, teachers delivered reasonable assignments which interrelated both ICC aspects and one of 4 skills together. Teachers shared the differences and similar among cultures. As Durocher (2007) argued that interculturalcommunication comprises skills (e.g., cultural adaptation strategies) that are both distinct from, and complementary to, language proficiency. Therefore, teachers could limited the obstacles happened in EFL classroom.

4.4. Suggestions for challenges of integration of learning ICC and four language skills through AEF2 textbook (Unit 1 to 5$)$

In order to reform the objective of the study, the researcher interviewed some students who pointed out and shared the benefits of teachers' practices bring to EFL classroom as the benefits of learning L2 output process. These below students' voice made clear what common challenges of them came from and how they overcome those drawbacks as potential solutions:

"[...] I think working part-time job at a restaurant where serve a lot of foreigners as travelers. I can practice English pronunciation and feel confident. Besides, I will save time to prepare the lessons for the following learning periods it helps me understand the English task clearer. Also, I will get some foreign friends from social network so I enable to speak English with them and my speaking and listening English skill will improve fast. Anyway, I can know many different cultures of foreigners all over the world.In my classroom, I try to listen Listening part and take notes down as my teacher guidance. I try to read some difficult word as American accent and answer the question samples as teacher's instruction."

(Student 1) 
"[...] I want to improve my listening and speaking skill before graduation. Therefore, I am going to search Internet or watch Youtube channel for learning some new idioms as well as slang of L2 local people. Facebook is a good tool for me to watch American film with American subtitle version. Moreover, I think listening to US or UK songs may make me enhance my English listen skill and know how to express my ideas by simple sentences. In summertime, I am going to apply for a job as a tour guide. Hence, I may have opportunities to speak English with foreign travelers and introduce to expats Vietnamese cultures and collect knowledge about foreign cultures of other countries."

(Student 3)

The finding from the data interview showed that the participants prefer using ICT tools, extra materials to using other options for teaching ICC and four language skills through AEF2 textbook as well as learning. When researcher asked them about ICT tools perception, interviewers were willing to answer clearly and they knew how to use these supporting tools in teaching and learning ICC and four language skills. Also, teaching and learning ICC and four language skills have may benefits and challenges in that. From teachers' opinions and contribution, teachers would use ICT tools, extra materials or other options effectively in integrate ICC to four language skills at foreign language center, and they hope that their headmaster, managers as well as administrator of the center can enhance facilities in center such as high-tech devices, room lights, stationery. Also, the foreign center is going to organize some extra classes for teaching and learning ICC with more and more real activities with native speakers in order to know more about foreign cultures. Students hope their teachers enable to communicate with them through social network (Facebook, Zalo, Zoom) to feedback students' questions immediately. Extra materials will be maintained to illustrate English lessons and ICC contents clearly. Some activities or games should be eliminated because of its less applicable such as words chains, claps the board.

\section{Conclusions}

\subsection{The summary of the study}

The current study illustrates to what extent EFL teacher's teaching ICC and four language skills (Speaking, Listening, Writing, Reading) through "American English Files 2" textbook by supporting tools (ICT tools, extra materials, other options). The study's results show that EFL teacher's perception for their teaching practices. Similarly, teacher's decisions belong to their reasons in choosing supporting tools while teaching ICC and four language skills. At the same time, teachers mentioned to their challenges in teaching as well as in what ways they overcome those challenges and suggestions for using supporting tools in teaching ICC effectively. The study was conducted with ten EFL teachers for both quantitative and qualitative and three students for qualitative only from a foreign language center in Mekong Delta. The two main instruments of the study which collect quantitative and qualitative data were questionnaire and interviews.

The findings have figured out EFL teachers prefer using ICT tools, extra materials to other options because they think these tools are useful and necessary for teaching ICC and four language skills. Teachers like integrating ICC and language skills because students feel practical and realistic. While they are exposing English, they can also discovery ICC sides such as traditional holidays, customs, music, great buildings, architectures, local people lifestyle, historical events, and climate in foreign countries; specially European and Americans. Thorough five lessons, students can use structures samples for getting specific information which depend on individual purposes. They realize the importance of using suitable sentences in both making questions and response, get more beneficial techniques in learning skills for avoiding cultural barriers. Effective intercultural communication occurs when meaning is both shared and constructed.Language and culture are deeply connected, in that culture shapes language use and languageconveys cultural meanings (Kramsch, 1993).Without shared assumptions, values, and beliefs, communication can be difficult or awkward, asinterlocutors need to overcome both cognitive and affective barriers (Byram\& Feng, 2004;). Therefore, teacher's perception in teaching ICC is properly high lead to their frequencies of integrating ICC and language skills through AEF2 textbook by extra materials are high rather than ICT tools. Teachers guide students in the acquisition of various skills, contribute to the development of their knowledge and understanding of a target language, help students reflect on their own culture as well.

The findings explained EFL teachers created students' motivation and curiousness in learning the topics, encouraged them use smart phone for search information in speaking activities. However, students avoided use Google translate app for reading tasks. On the other hand, designing PowerPoint lessons and watching video bring not only for students' joyfulness but also their attentions. It depended on facilities which were equipped in classrooms that teachers chose suitable methods. Consequently, teachers can create the interaction among students, 
four language skills' lessons, ICC, and supporting tools.

The devices were usually used namely $\mathrm{CD}$, cassette players, USB, projectors, TV, laptop, and smart phones. The most useful convenient tools for teaching like software which teachers usually preferred using such as Microsoft Words, Power Point. Teachers showed the available contents related to cultural regions, national languages, and foreign culture in PowerPoint screen slides. Among ICT tools (video clip, PowerPoint, CD, cassettes, USB, music players, speakers, projectors), or extra materials (lessons outline, portfolios, handout, note papers), or other options (pictures, markers, "Cross and Nought" games, practicing mini conversation, role-play, quiz, multi-choice questions), EFL teacher prioritized to choose ICT and extra materials for integrating ICC to four skills. If the classrooms weren't equipped technology facilitates, some teachers decided to use white board and markers pen. These options also bring many advantages in case of many meaningful useful information of textbook so teachers do not explore more outside the textbook or add more extra materials or ICT tools.

The EFL teachers taught ICC and language skills by extra materials that helped students felt easy to follow teachers' instruction for text samples. Teachers designed portfolios for students' group working, or individually. Some of teachers said that all of portfolios need clear, not ambiguous. Teachers describe types of extra materials based on AEF2 textbook contents which follow the standards and processes (pre-; while; post-) with puzzle or jigsaw approaches. Extra materials were designed by teachers in order to change students' learning styles from learning by heart to applying. Students are able to get acquainted with native speakers' accent. Moreover, teacher' lesson plans led to students' motivation in learning. Learners have ability to make questions about festivals topics, getting personal information, making mini-conversation follow the mentioned lessons.

Concerning the main difficulties facing teachers in using supporting tools to teach ICC and four language skills, the interviewees reported that the difficulties were lack of special books or reference books for some majors, lack of environment for practicing English with native speakers. Some students only study English for chasing certificates. The mixed-level classes were very common that contained both high-English level proficiency students and the low one. Additionally, both the number of female as well as male and large-size classes were imbalance and large. Therefore, different background and knowledge foundation create the big gap among students learning ICC outcome. Besides, EFL teachers' motivation in teaching L2 was impacted by students' learning behaviors, lack of sense of responsibility.

Students found difficult in speaking because of low-level academic vocabulary. Students also faced listening challenges named reduction sounds, special expressions, and idioms that make students embarrassed and confused. Some challenges of students in learning ICC and four language skills processes were no English sub on the screen slide, containing new vocabulary and difficult long sentences in the important parts, not enough time for group work and discussion. In the fact that, students' bad habits that translating English conversation in listening part into Vietnamese made them take times and skip important part for choosing the correct answer. Those reasons led teachers focus on checking students' comprehension rather than widening their knowledge in term of ICC contents from textbook in some cases.

In conclude, teaching ICC and language skills through the English textbook by supplementary resources is the new concept of foreign language center in Mekong Delta context. Although ICT tools were received more attention, extra materials were still more commonly used in teachers' lesson designs and teaching processes. Teaching still faces many problems due to the influence of factors such as class size, student's level, tight syllabus of teaching, the time limited of curriculum, and school facilities.

\subsection{Pedagogical implications}

The findings from this current express several pedagogical implications for EFL teachers and administrators about using supporting tools for teaching ICC and four languages skills which combined with AEF2 textbook contents (Unit 1 to 5). Mentioning ICC contents of textbook played one of the main factors but not the only main part in teaching process. Teachers finally need to mix both ICC and language skills in order to motivate students' learning spirit.

To the EFL teachers, they should redesigned teaching all lesson plans with the purpose integration of teaching ICC and four language skills. Lecturers teach not only each single skill but also skills together. Similarly, teacher addressed intercultural features into specific tasks or lessons of the textbook that motivate students in the voluntary language acquisition process. At the same time, teachers should emphasize the cultural factors and benefits of intercultural communication thanks to the English skills that have been trained to encourage the voluntary of learning autonomy processes through skillfully manage multiple tasks by additional teaching resources. 
Besides, EFL teachers should develop the integration of teaching ICC and skills more and more. Also, they need to establish a group online diary on social network to share their difficulties in conducting teaching ICC and skills in classroom, or evaluation of students' learning process and their difficulties need to be improved during learning. On the other hand, students sometimes neglected while they were watching video or looking at PowerPoint screen slides. Then, they turned into using cell phones for looking up vocabulary or chatting with friends. Therefore, teachers should catalogued pre-task, main-task, post-task in detail that connected students to lessons' effects. Instead of teaching as the traditional way, teachers concentrated on teaching more frequently by using supporting resources rather than using textbook contents only because of some textbook's contents and language skills are mutually incompatible under Vietnamese contexts.

For EFL teachers, they should award to examinees who win the highest score in the test. Moreover, they have to enhance their professional development by signing up ICC and teaching L2 workshop, English teaching methodology workshop, seminars or further training courses. EFL teachers should design mini tests for students to evaluate and adjust students learning's process. It would be a good idea if EFL lecturers recommend some beneficial resources or website which students must visit for better learning outcome.

For administrative council, they should organize diagnostic test and formative tests, instead of final test only.Facilities need to be equipped and upgraded such as TV, load speaker, light systems, or classroom decoration. Additionally, I would recommend creating English online assignments so learners could access to website or use app to do their homework. Therefore, school administrators can manage students' learning output. They would be easy to compare students' improvement among periods. Besides, foreign language officers had better open a forum on social network for students exchange information together as well as admin of our center feedback learners effectively. It was reasonable to increase the current tuition for the future plans of improvement the quality of teaching at center which principal and administrators need to consider.

\subsection{Limitations}

This study has gathered the integration of EFL teachers' teaching ICC and four language skills, teachers' perception in teaching AEF2 textbook, as well as the reasons for teaching were found out in this section. Consequence, the researcher also attempted to assure reliability and validity. However,
EFL teachers have not designed the specific tests which are contained both ICC and 4 language skills, instead of common tests (including four skills only). A system for evaluation ICC competence have not built or mentioned in any matrix scoring scale. Though teachers got high perception in the importance of teaching ICC contents in four skills, they totally confused in scoring students' performance under teaching skills with ICC contents parts. Besides, teachers' interviewing took place under coronavirus disease (Covid-19) season so this process had interpreted several times. Teachers had to wait the announcement until teaching L2 class become active again. The students' interviewing sections only implied as references which show a limited aspects of teaching process of EFL teachers. Moreover, EFL teachers' perception of integration of teaching ICC and four language skills that its major reasons came to their experiences and their subjective ideas. Teachers recognized and evaluated students' involvement thorough their subjective lens lead to the high fluctuation between teachers' prediction and final results of students' tests achievements.

\subsection{Suggestions for further research}

This research is one of the primitive study which analyzed to teach both ICC contents and English skills together thorough AEF2 textbook in Mekong Delta. The future researcher may take advantages from the precious information of this study in order to extend their future studies. Firstly, others researchers can measure the effects of using supportive application into teaching ICC contents and students' reaction in term of non-English major students classroom. Secondly, potential researchers may do more research related to students' perception or students' reaction about learning ICC in L2 environment. Thirdly, they perhaps design the studies about the application of ICC contents into teaching and developing students' ICC competence under ESL classroom.

\section{Acknowledgments}

The authors would, first and foremost, like to express their sincere thanks to lecturers at Can Tho University (CTU) Vietnam, those School of Foreign Languages (SFL), and especially those from School of Social Sciences \&Humanities (SSSH), Can Tho University, CTU, for their teaching and supervisions towards the Master Program in Teaching English to Speakers of Other Languages (TESOL), especially to Dr. Thai Cong Dan for his effortless to proofread this paper and the researchers' MA classmates of Cohorts 23, 24 and presently 25 . Secondly, their great thanks would go to EFL teachers and students in an English center in Can Tho City, in the Mekong Delta 
Vietnam for their kind co operations to the research through the questionnaires, and interviews face-toface and online meetings. And last but not least, their great and deep thanks would go to IJASRM journal board for thispaper in a series to be published to world readers, especially those interested in teaching and learning English in Vietnamese high school level on the path towards the global environment.

\section{References}

[1] Argyle, M. (1982). Inter-cultural Communication. In S. Bocner, (Ed.), Cultures in Contact (pp. 61-79). Oxford: Pergamon Press.

[2] Barrett, M, Byram, M, Lázár, I, MompointGaillard, P., \&Philippou, S. (2013). Developing Intercultural Competence through Education. Strasbourg: Council of Europe.

[3] Benahnia, A. (2012). The Role of Cultural Components in Shaping the L2 Learner's Identity and Intercultural Competence. Available on http://www.ksaalt.org/conference_proceedi ngs.html/ 2012.

[4] Best, J. W., \& Kahn, J. V. (2006). Research in education (10th ed.). Boston: Pearson Education.

[5] Bidhan A. (2010) Questionnaire design

[6] Blanka K. (2013), Approaches to the Teaching of Writing Skills

[7] Byram, M. (1997). Teaching and assessing intercultural communicative competence.Clevedon, UK: Multilingual Matters.

[8] Byram, M. Gribkova, B. \& Starkey, H. (2002). Developing the Intercultural Dimension in Language Teaching. Council of Europe. Strasbourg. Retreived 14- 04-08 from

http://lrc.cornell.edu/director/intercultural.p

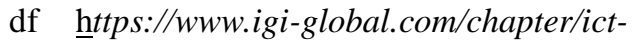
interculture-opportunities-offeredweb/37621

[9] Brown, Douglas H. 2001. Teaching by Principles: An Interactive Approach to

\section{[10]Language Pedagogy.New York:} Addison Wesley Longman, Inc.

[11] Celeste Bickley, Marian J. Rossiter, \& Marilyn L. Abbott (2014) Intercultural Communicative Competence: Beliefs and
ISSN 2455-6378

Practices of Adult English as a Second Language Instructors

[12] Christina L. K., C. O., P. S., \& M. B. (2008) American English Files series. Oxford University Express.

[13] Corbett, J. (2003). An intercultural approach to English language teaching. Clevedon, England: Multilingual Matters.

[14] Crozet, C., \& Liddicoat, A., J. (1999). The challenge of intercultural language teaching: Engaging with culture in the classroom. In J. L. Lianco, A. Liddicoat, J \& C. Crozet (Eds.), Striving for the third place intercultural competence through language education (pp. 113-126). 1999: The national languages and literacy institute of Australia

[15] Cullen, P. (2000). Practical Techniques for Teaching Culture in the EFL Classroom. The Internet TESL Journal (online) VI(12). Retrieved from http://iteslj.org/Technuques/Cullenculture.heml

[16] Deardorff, D. K. (Ed.) (2009). The SAGE Handbook of Intercultural Competence. Thousand Oaks, CA: Sage Publications.

[17] Dornyei, Z. (2007). Research methods in applied linguistics. Oxford: Oxford University Press

[18] Derin A. (2009) The Role of Intercultural Competence in Foreign Language Teaching 135

[19] Dudley-Evans, T., \& St John, M. (1998). Developments in English for Specific Purposes. Cambridge: CUP.

[20] Durocher, D. O. (2007). Teaching sensitivity to cultural difference in the firstyear foreign language classroom. Foreign Language Annals, 40(1), 143-160. doi:10.1111/j.1944-9720.2007.tb02858.x

[21]Ge, W. (2003). Task-based intercultural language teaching in EFL classroom. Paper presented at the First Asia TEFL International Conference, Pusan South Korea.

[22] Gibbons, Pauline. Bridging Discourses in the ESL Classroom: Students, Teachers and Researchers. Continuum, 2006.

[23] Gilakjani,A.P. and Ahmadi, M.R. (2011). A Study of Fctors Affecting EFL Learners' English Listening Comprehension and the Strategies for Improvement. Journal of 
Language teaching and Research, Vol, 2, No. 5, pp. 977-988.

[24] Guest, M. (2002). A critical 'checkbook' for culture teaching and learning, ELT Journal, 56(2), 154-161

[25] Masoomeh E., Ali R. (2018) Exploring Teachers' Perception of Intercultural CommunicativeCompetence and their Practices for Teaching Culture in EFLClassrooms

[26] Hamouda, A. (2013). An Investigation of Listening Comprehension Problems Encountered by Saudi Students In The EL Listening Classroom. International Journal of Academic Research in Progressive Education and Development, 2(2). 113- 15.

[27] Hismanoglu, M. (2011). An investigation ofELT students' intercultural communicativecompetence in relation to linguisticproficiency, overseas experience andformal instruction. InternationalJournal of Intercultural Relations,35(6), 805-817

[28] Iberri-Shea, G. (2009). Using Public Speaking Tasks in English Language Teaching. English Teaching Forum, 47(2). 18-29.

[29]Issa, A. A. (2016). The Meaning and Theories of Intercultural Communication. https://doi.org/10.13140/RG.2.2.14026.368 $\underline{06}$

[30] Jæger, K. (2001). The Intercultural Speaker and Present-day Requirements

[31]Regarding Linguistic and Cultural Competence.Sprogforum, 19, 52-56.

[32] Johnson BR, Onwuegbuzie AJ, Turner LA. Toward a definition of mixed methods research. Journal of Mixed Methods Research. 2007;1:112-133. doi: 10.1177/1558689806298224. [CrossRef] [G oogle Scholar]

[33] Kramsch, C. (1993). Context and culture in language teaching. Oxford: Oxford University Press

[34] Krashen, S. (1985). The input hypothesis. New York: Longman.

[35]Lee, C. D. \&Smagorinsky, P. (Eds.). (2000). Vygotskian perspectives on literacy research: Constructing meaning through

\section{ISSN 2455-6378}

collaborative inquiry. New York: Cambridge University Press.

[36] Liddicoat, A. J., Crozet, C., \& Bianco, J. L. (2000). Striving for the third place: Consequences and implications. In J. Bianco, A. Liddicoat, \& C. Crozet (Eds.), Striving for the third place: Intercultural competence through education (pp. 184185). The National Languages and Literacy Institute of Australia.

[37]Liu, S. \&Laohawiriyanon, Ch. (2013). Cultural Content in EFL Listening and Speaking Textbooks for Chinese University Students. International Journal of English Language Education, 1(1), available on www.macrothink.org/ijele

[38]Lustig, W., Myron, \& Koester, J. (2010). Intercultural Competence: Interpersonal Communication across Cultures. (K. Bowers, Ed.) (6th Ed.). UnitedStates: Pearson

[39] Mackey, A., \&Gass, S. M. (2005). Second language research: Methodology and design. New Jersey: Lawrence Erlbaum Associates

[40] Marin, M. \&Pava, L. (2017). Conceptions of Critical Thinking from University EFL Teachers. English Language Teaching 10.7, 78-88.

[41] Masoomeh E., Ali R. (2018) Exploring Teachers' Perception of Intercultural Communicative Competence and their Practices for Teaching Culture in EFL Classrooms

[42] Merriam, S. B., \& Simpson, E. L. (2000). A guide to research for educators and trainers of adults. Malabar, FL: Krieger

[43] Moore, L. S., \&Detlaff, A. J. (2005). Using Educational Games as a Form of Teaching in Social Work. Arete. 29(1), 58-72.

[44] Mortimer, Eduardo, and Philip Scott. Meaning Making in Secondary Science Classrooms. Open University Press, 2003.

[45] Newton, J., Yates, E., Shearn, S., \& Nowitzki, W. (2010). Intercultural

[46] Communicative Language Teaching: Implications for Effective Teaching and 
[47]Learning. In Report to the Ministry of Education Ministry of Education,

[48] New Zealand. Retrieved from http://www.educationcounts.govt.nz/ publications/curriculum/76637/intro duction

[49] Nunan, D. (1989). Designing tasks for the communicative classroom. Cambridge: Cambridge University Press.

[50] Piyusha S. S. \& Asha V. T. (2018): Crossword Puzzle: An Active Learning Strategy

[51] Raja, H., Qureshi, R. \&Albesher, B. (2017). Application of Cooperative Learning Strategies (CLS) for Students' Focused Teaching (SFT) in EFL Class: An Experimental Study in the Summer Remedial Course for Adult Learners. Journal of Language Teaching and Research, 8.2, 237-252.

[52] Schmidt, R. (1995). Consciousness and foreign language learning: A tutorial on the role of attention and awareness in learning. In R. Schmidt (Ed.), Attention and awareness in foreign language learning (pp. 1-63). Honolulu, HI: University of Hawaii, Second Language Teaching \& Curriculum Center.

[53] Schmidt, R. (2001). Attention. In P. Robinson (Ed.), Cognition and second language instruction (pp. 3-32). Cambridge: Cambridge University Press.

[54] Siddiqie, S. A. (2011). Intercultural exposure through English language teaching: An analysis of an English language textbook in Bangladesh. Journal of Pan-pacific Association of Applied Linguistics, 15(2), 109-127.

[55] Sanders, W. L. (1998). Value Added Assessment. School Administrator, 11(55), 24- 27.
[56] Thanh, L. T. (2005). Teaching and learningAmerican studies at the School of Foreignlanguages-Ho Chi Minh Open University: Challenges and solutions.

[57] Thao, Q. T., \&Sirinthorn S.(2015). A Proposed Framework for EFL Learners' Intercultural Communicative Competence Development in the Vietnamese Context.

[58] Tomalin. B. \&Stempleski, S. (1993). Cultural Awareness. Oxford: Oxford

\section{[59] University Press.}

[60] Zhang, Y. (2010). Cooperative Language Learning and Foreign Language Learning and Teaching. Journal of Language Teaching and Research 1.1, 81-83

[61] Wahyuningsih, N. (2009). A study on the role of crossword puzzle in developing speaking proficiency.Bistek Journal BisnisdanTeknologi, Volume 17, (1), 44-50 http://ppublishing.org/journals/337/issue/33 678/articles/3449/

[62] Walsh, K. (2010). The importance of writing skills: Online tools to encourage success. Retrieved December 27, 2012, from

http://www.emergingedtech.com/2010/11/th e-importance-of-writing-skills-online-toolsto-encourage-success/.

[63] Yen-Chen Yen, Huei-Tse Hou \&Kuo En Chang. (2013). Applying role-playing strategy to enhance learners' writing and speaking skills in EFL courses using Facebook and Skype as learning tools: a case study in Taiwan. Computer Assisted Language Learning 28.5, 383-406.

[64]Ziaei, S. (2012). Examining cross-cultural clues as to globalization and Iran's culture in an international ELT book series: American English file. MJSS [2039-2117]. Jan; 3(1):[about8p.].Retrievedfromhttp://www.m cser.org/index.php?option=com _content\&vi ew $=$ article $\& i d=3 \&$ Itemid $=54$ 